\title{
"Mostrar, no decir": The Influence of and Resistance Against Workshop Poetics on the Hispanic Literary Field
}

\author{
Andrés Franco Harnache
}

\section{INTRODUCTION}

By the end of 1607, Félix Lope de Vega, went to the Academy of Madrid, then an association of noblemen, to read a small ars poetica with the intention of defending his comedias. Just after the release of El vardero amante and Los hechos de Garcilaso de la Vega (1585, The Real Lover and The Facts of Garcilaso de la Vega), the Sevillian had become the bestknown playwright in Madrid to the extent that, by the turn of the century, he had obtained the monopoly of the theatrical milieu, forcing other writers, like Cervantes, to print theirs plays instead of producing them on stage. The critiques did not take long to appear. His peers accused him, sometimes rather violently, of letting down the unquestionable theatrical laws set forth by Aristotle and Horace. Lope, "a brave horse without bridle," as Góngora, one of his contenders, called him (2006, n.p., my trans.), was tired of the rigidity of the classical norms and created a new

\footnotetext{
A. Franco Harnache $(\varangle)$

Université Catholique de Louvain, Ottignies-Louvain-La-Neuve, Belgium

(C) The Author(s) 2021

A. Masschelein and D. de Geest (eds.), Writing Manuals

for the Masses, New Directions in Book History,

https://doi.org/10.1007/978-3-030-53614-5_14
} 
type of theater based on the tastes of the Spanish public, a mixture of comedy and tragedy without respect for the unities of space and time. Aware of his own value, El Fénix, as people knew him, claimed in front of the noblemen of the academy that although he knew the Greek and Latin precepts by heart, he deliberately decided to keep them in his drawer, choosing instead to please the tastes of the people, who actually were paying him. Early on in his manifesto, he summarizes his ars poetica:

True it is that I have sometimes written in accordance with the art which few know; but, no sooner do I see coming from some other source the monstrosities full of painted scenes where the crowd congregates and the women who canonize this sad business, than I return to that same barbarous habit and when I have to write a comedy I lock in the precepts with six keys, I banish Terence and Plautus from my study that they may not cry out at me; for truth, even in dumb books, is wont to call aloud; I and I write in accordance with that art which they devised who aspired to the applause of the crowd; for, since the crowd pays for the comedies, it is fitting to talk foolishly to it to satisfy its taste. (Lope de Vega 1914, p. 24)

The reception of Lope's Arte nuevo de hacer comedias (The New Art of Writing Plays), read in front of the members of the Academia and published afterward in the poetic anthology Rimas (1609, Verses), was mixed. Francisco Cascales called Lope's plays "hermaphrodite monsters" and "frights" (1617, n.p.), and Cervantes, through the voice of the priest in Don Quijote, questioned Lope's inclination to favor the taste of the public without considering its literary value (2003, pp. 556-557). Moreover, disciples of Lope, like Calderón de la Barca, took Lope's precepts and mocked them in plays like La dama duende (1629, The Phantom Lady). By the eighteenth century, Lope's comedias would go out of style, while the Hispanic literary field began to favor classicist French literature, and to establish a neo-classical literature guided by Ignacio de Luzán's La Poética (1737, The Poetic) and the moral plays of Tomás de Iriarte (1750-1791).

Taking this example from the theatrical milieu, I propose that Lope's defiance of classical prescriptions is characteristic not only of his own persona, writing and time, but of a more general tendency in the Hispanic literary field. ${ }^{1}$ Since the sixteenth century, known as the Spanish Golden Age (Siglo de oro), Hispanic literature has been caught between the influences of outside literary traditions (including the Greek and Latin 
classics, the Italian dolce stil novo and since the eighteenth and nineteenthcentury French and Anglo-American realism), and its own literary norms. Hispanic literature, due to a combination of pride, geographic isolation, and cultural hybridity, has constructed a rich canon of its own, which, as Borges advocates in El escritor argentino y la tradición (1932, The Argentine Writer and Tradition), speaks with the other major European traditions, but also to a greater or lesser extent functions largely outside of those norms. Such was the case, for instance, of the so-called Boom generation in the second half of the twentieth century, where writers such as Gabriel García Márquez, Mario Vargas Llosa, Elena Garro, Marvel Moreno, Juan Goytisolo, and Julio Cortázar ${ }^{2}$ appropriated the modernist poetics of other US/European literatures (James Joyce, Virginia Woolf, William Faulkner, Samuel Beckett, etc.), in order to create something new. According to Randolph Pope, Boom literature:

relied on a Cubist superposition of different points of view, it made time and lineal progress questionable, and it was technically complex. Linguistically self-assured, it used the vernacular without apologies [and] used innovative techniques that were tingly bound to a political message: anti-elitist, progressive, anarchic. (Pope 1996, pp. 231-232)

Today, the emergence of academic programs for Creative Writing in Spanish, first in the United States and subsequently in Latin America and Spain, and the ensuing proliferation of literary advice handbooks, has led to the imposition of new rules, the poetics of the North-American workshop: "read like a writer," "find your own voice," and "show don't tell" (Dawson 2005, pp. 87-112).

In what follows, I outline the existing Hispanic writing advice tradition, which until recently stuck to the Romantic view of the writeras-genius. This tradition began to change by the end of the twentieth century, due to both US literary and MFA influence. However, even if the "program," as Mark McGurl calls it (2009), became increasingly influential in the Hispanic field, some contemporary authors now resist, in the spirit of Lope, the pressures of normative creative writing poetics. 


\section{A Short History of Creative Writing Advice in the Hispanic World}

According to Fraile Amador in Textos sobre escritura creativa: el origen de una disciplina (2018, Texts About Creative Writing, The Origins of a Discipline), there has been for a long time a lack of literary advice texts on the Hispanic literary world. This can be explained by the tendency to see writers as Romantic geniuses and their work as a product of inspiration. Although, as in other countries, the serial novel and the short story industry developed in the nineteenth century, and despite the appearance of some masters of the genre, like Benito Pérez Galdós, Horacio Quiroga, and Rubén Darío, there was no concomitant advice tradition, as Andrew Levy describes for the United States (Levy 1993, pp. 77-107). As Leopoldo Alas, also known as Clarín, explains when talking about Spain's nineteenth-century short story industry in La prensa y los cuentos (1896, Press and Short Stories): the field was full of dilettantes without technical knowledge of what they were doing.

Even authors with more expertise, such as Ruben Darío, the Nicaraguan writer who spearheaded the modernist revolution in both Latin America and Spain by the end of the nineteenth century, and who was a ferocious critic of the Iberic literary establishment, ${ }^{3}$ remained attached to the Romantic conception of the writer and rejected the idea of transmission of the literary craft. In the manifesto that serves as the introduction of Prosas profanas y otros pemas (1896, Profane Prose and Other Poems), he proclaims that "my literature is not to set others on their course" (Darío 1915b, pp. 47-48, my trans.). In Historia de mis libros (History of my Books), he explains, in what resembles the endeavors of Poe in "The Philosophy of Composition," his approach to composing poetry but ends with a simple summary of influences, rather than proposing a treaty on the technical aspects of his writing. The savoir faire of literature remains a mystery to most, save for the privileged few, as one might conclude from his autobiography La vida de Rubén Darío escrita por él mismo (1915a, The Life of Rubén Darío Written by Himself), where he describes himself as a gifted poet at the age of eight. Some years later, Juan Valera's Apuntes sobre el nuevo arte de hacer novelas (1934, Outlines for a New Art of Writing Novels), borrowing Lope's defense in his Arte nuevo, is written from the perspective of a critic, rather than that of a professional offering advice on how to plan, 
write, and publish a novel, as in the handbooks popular in the United States by 1930 .

With the Boom generation, a generation more in contact, as Darío desired, with other European literary traditions, the Romantic idea of a writer started to fade. Raised in newsrooms, like García Márquez, or in academia, like Mario Vargas Llosa and Octavio Paz, this generation is less romantic and more practical in their conception of the literary career. Still, the idea of writing as a teachable skill, and therefore as a subject of academic instruction, had yet to emerge. The figure of the writer as a lonely creator was confirmed and mystified by the paratexts surrounding the literary success of novels like Cien años de soledad (1967, One Hundred Years of Solitude). In a 1976 interview with the reporter German Castro Caycedo, for instance, the future Colombian Nobel-Prize winner García Márquez describes the genesis of his better-known work as a lonely process without workshops, in times of desperation and poverty (first in Paris and then in Mexico City), thus reinforcing the Romantic myth of the starving and solitary artist.

By the time of this interview, however, writing workshops had become popular in some southern South American countries (Fraile Amador 2018, p. 388). Nevertheless, the format was not identical to their US counterparts: they were mostly outside of academia and did not have any theoretical basis. For instance, A la hora de escribir (1988, When writing), a transcript of the workshops led by Bioy Casares in the 1980s, shows the workshop as a closed-door interview where assistants or disciples ask for the master's advice, without any commentary on their own texts. One of the concerns raised here is the possibility of teaching literary writing. The Argentinean author confesses that he does not believe that the creation of literature can be taught, yet he still asserts that workshops are ideal places to establish a network, or as he puts it, places where "one can find people to whom literature is something real, something important" (Bioy Casares 1988, pp. 106-107, my trans.). Likewise, in a 1999 lecture to aspiring writers, Carlos Fuentes warns that "books are not written themselves, neither are they (written) in a committee" (Fuentes 1999, n.p., my trans.). Not "in a committee" means not in group, and therefore by extension, not in workshops. Mario Vargas Llosa, by contrast, is the Boom writer more in agreement with a creative writing approach. While not involved in workshops himself, he wrote two advice books, Historia secreta de una novela (1971, The Secret Story of a Novel) and Cartas a un joven novelista (1997, Letters to a Young Novelist). In the latter, 
which recalls E. M. Forster's Aspects of the Novel (1927), he discusses subjects such as point of view, construction of characters, use of time, etc., while repeating the well-known adage that talent is innate, but must be cultivated.

However, by the time Fuentes gave his conference at the Monterrey Institute of Technology and Higher Education, and Vargas Llosa published his advice books, a new generation of Hispanic writers, more connected with the North American literature and the workshop poetics, had spread across the continent. A post-Boom generation of writers born after the Cuban Revolution (1959) were distancing themselves from their predecessors, in order to forge their own positions in the literary field. Leaning toward the American standards of the workshop, they broke with the predominance of politics in literature, the prevalence of indigenous and naive subjects, and most importantly, with the dominant current of magical realism. This generation was marked by two manifestos: $\mathrm{McO}$ Ondo (Chile) and Crack (Mexico), both of 1996.

The 'McOndo' group was the more radical of the two in its opposition to their literary predecessors. ${ }^{4}$ Interestingly, this group adopted a paradoxical relationship to the American creative writing workshop. In the introduction to the short stories collection McOndo (1996), which would thereafter serve as a manifesto, Alberto Fuguet explains that he was invited to "the most important factory/workshop of new North American writers," University of Iowa International Writing Program (Fuguet and Gómez 1996, p. 9. my trans.). His initial surprise at seeing the popularity of Hispanic literature in this context, soon turned into disappointment. After being first contacted and then rejected by an American editor, he became aware that the interest of the US market for Hispanic literature was limited to the stereotypes of magical realism. By then, he and other young Latin-American writers in the program had already been creating a more urban literature which, as Fuguet suggested, could be written in any country of the first world. Their short stories, for instance, not only treated more urban subjects, but also complied with standard workshop poetics which had already begun to make their influence.

Thus, Fuguet and his Chilean colleagues developed a new literature in the workshop of the magazine Zona Contacto, with settings in big cities with metros and shopping malls, populated with characters who neither fly nor are immortal, but instead listen to punk music and take drugs. The Mexican authors of the 'Crack' group, although more respectful of the Boom legacy, also wanted to keep their work clear of folklore and magical 
realism. Wanting to live more in McOndo than in Macondo, the Hispanic writers born after the Cuban revolution (1959) entered the twenty-first century with one foot in the US tradition, and in this way, with an eye on 'the program' and workshop poetics.

\section{From Boom to MFA: The Rising Influence of Creative Writing Programs in Twenty-First-Century Hispanic Literature}

The path from Boom to MFA can be traced via three lists: 'Bogotá 39,' in its 2007 and 2017 versions, and the selection made by Granta Magazine in 2010. Taken together, they more or less offer a complete overview of contemporary Hispanic production. ${ }^{5}$ The first was proposed by members of the Hay Festival Cartagena and the coordinators of Bogotá UNESCO 'World Book Capital' in 2007. The jury, formed by three Colombian writers, selected thirty-nine Latin-American authors, all younger than thirty-nine, with the intention of promoting a new post-Boom generation forty years after the publication of One Hundred Years of Solitude. The selection known as 'Bogotá 39' consisted both of well-known writers, such as Crack's founder Jorge Volpi (Planeta Prize 2012 and Alfaguara Prize 2018) and writers who would later be consecrated, like Juan Gabriel Vásquez (Alfaguara Award 2011, Le Prix Cabaret des Lycéens 2016, shortlisted for the Man Booker International Prize 2019), Junot Díaz (Pulitzer 2008), and Antonio Ungar (Anagrama Prize 2010), among others.

Three years later, Granta Magazine (the magazine which became famous for its lists of 'Britain's best young novelists' (1983, 1993, 2003, and 2013) and 'America's best young novelists' (1996, 2007, 2017) made, under the leadership of Valerie Miles, a special issue on Hispanic literature taking advantage of the posthumous success of Roberto Bolaño in the US market. ${ }^{6}$ The Granta list not only aimed at fueling the Hispanic market, but also sought to promote the promise of the new Hispanic generation for the dominant Anglophone audience. With only four overlaps with the 'Bogota 39' list, the Granta list filled the gap of Spanish writers in the first 'Bogotá 39' and added names that would garner critical recognition, like Samanta Schweblin, whose Distancia de rescante (2014, Fever Dream) was an International Booker Prize finalist in 2017, Andrés Barba (Anagrama Prize 2017), and Patricio Prom (Alfaguara Prize 2019). 
Finally, ten years after the first 'Bogotá 39,' the Hay Festival decided to create a new list, this time with a more mixed jury of already-established authors including Leila Guerriero (Argentina), Carmen Bullosa (Mexico), and Darío Jaramillo Agudelo (Colombia). The list still favored the underrepresented Latin-American market, but also included small and regional publishing houses, besides the most known and transnational ones like Alfaguara and Planeta.

If we take a closer look at the education level of the authors, a sociological change in the Hispanic field becomes clear. In both lists, we see a predominance of writers with a BA or MA in literature, and a significant number of PhDs (see Table 14.1), particularly in regions where this title is an actual privilege. Moreover, most of those listed have traveled to Europe or to the United States to complete their studies, or, when they followed educational paths in their own countries, they eventually went abroad to increase their chances of notoriety, especially to Spain, which became the center of the Hispanic publishing world after the 1960s (Ayén 2014, pp. 75-115).

Unlike the Anglophone authors, who since the early selections in Granta's lists came from the workshop milieu, confirming McGurl's thesis that postwar American fiction is dominated by the 'Program,' the Hispanic writers of the 2007 'Bogotá 39' and the Granta list rarely followed MFAs in creative writing. Those connected to academia, teach mostly literary criticism, rather than literature as a generative art form. In the 2007 'Bogotá 39,' there is only one author with an MFA, Junot Díaz. ${ }^{7}$ His inclusion as a Hispanic author, however, is somewhat controversial, since he moved from the Dominic Republic to the States in his childhood, completed his education there, writes solely in English and is widely considered as an American writer.

In the Granta 2010 list, we begin to see a shift. On this list, only one author earned an MFA, Federico Flaco, but in contrast to Junot Díaz, he is an Argentinian who grew up in his country and who traveled especially

Table 14.1 New Hispanic generation by educational level

\begin{tabular}{|c|c|c|c|c|c|c|c|c|c|c|c|c|c|c|c|c|c|}
\hline \multicolumn{18}{|c|}{ New Hispanic Generation by Educational Level } \\
\hline \multicolumn{6}{|c|}{ Bogotá 392007} & \multicolumn{6}{|c|}{ Granta 2010} & \multicolumn{6}{|c|}{ Bogotá 392017} \\
\hline \multicolumn{2}{|c|}{ Education Level } & \multirow{2}{*}{$\begin{array}{c}\% \\
41.03 \\
\end{array}$} & \multicolumn{2}{|c|}{ Place of Education } & \multirow{2}{*}{$\begin{array}{c}\% \\
43.59 \\
\end{array}$} & \multicolumn{2}{|c|}{ Education Level } & \multirow{2}{*}{\begin{tabular}{|c|}
$\%$ \\
31.82 \\
\end{tabular}} & \multicolumn{2}{|c|}{ Place of Education } & \multirow{2}{*}{\begin{tabular}{c|}
$\%$ \\
54.55 \\
\end{tabular}} & \multicolumn{2}{|c|}{ Education Level } & \multirow{2}{*}{$\begin{array}{c}\% \\
43.59 \\
\end{array}$} & \multicolumn{2}{|c|}{\begin{tabular}{|l|l} 
Place of Education \\
\end{tabular}} & \multirow{2}{*}{$\begin{array}{l}\% \\
53.85 \\
\end{array}$} \\
\hline Bachelor & 16 & & Home Country & 17 & & Bachelor & 7 & & Home country & 12 & & \begin{tabular}{|l|l|} 
Bachelor \\
\end{tabular} & 17 & & Home Country & 21 & \\
\hline PhD & 12 & 30.77 & Europe & 11 & 28.21 & No edu. & 6 & 27.27 & N/A & 5 & 22.73 & No edu. & 4 & 10.26 & N/A & 4 & 10.26 \\
\hline No edu. & 4 & 10.26 & USA & 8 & 20.51 & $\mathrm{PhD}$ & 5 & 22.73 & USA & 3 & 13.64 & $\mathrm{PhD}$ & 6 & 15.38 & USA & 8 & 20.51 \\
\hline Master & 4 & 10.26 & N/A & 3 & 7.69 & Master & 2 & 9.09 & Europe & 2 & 9.09 & Master & 6 & 15.38 & Europe & 6 & 15.38 \\
\hline MFA Cine & 2 & 5.13 & & & & MFA CINE & 1 & 4.55 & & & & MFA Cine \&Art & 2 & 5.13 & & & \\
\hline MFA CW & 1 & 2.56 & & & & MFA CW & 1 & 4.55 & & & & MFA CW & 4 & 10.26 & & & \\
\hline
\end{tabular}


to the United States to do his MFA in Spanish. Here we see neither an enduring (or permanent) absence from Latin America, nor a change of language or of literary tradition. In the 2017 'Bogotá 39' list, the number of writers holding MFAs increases to four. The reason for this sudden change stems from the recent but rapid proliferation of MFAs in creative writing since 2006, which, to some extent, alter the future trajectory of the Hispanic literary field.

At the arrival of the twentieth century, Hispanic authors had two primary means of subsistence: academic career or journalism. ${ }^{8}$ Those options permitted authors to hold second professions besides writing, which, as Pierre-Michel Menger points out, continued to produce low profits, even in highly developed markets. ${ }^{9}$ Although the idea of going to school to learn how to write was still uncommon, it became more visible through the increased cultural influence of the United States. From the 1970s, the United States has received an increasing number of immigrants from Latin American countries due to their proximity and the high political and economic instability of the region. ${ }^{10}$ The population of Hispanic people in the United States rose from nearly 15 million in 1979 to 56 million in 2017 , bringing it to $17.6 \%$ of the total population and five points above that of African Americans, who, for a long time, comprised the largest ethnic group in the United States. ${ }^{11}$ This sudden change in demographics coincided with a cultural shift and a slow but unstoppable integration of Latin-American and US culture. The children of the newcomers, $20 \%$ of whom were illegal and living below the poverty line, entered the educational system, eventually achieving the roles of politicians, scientists, lawyers, and of course, writers.

The House on Mango Street (1984) by Sandra Cisneros was one of the first US novels written by a second-generation Latin-American emigrant. The novel, written in English, tells the story of a young girl of Mexican origin struggling to adapt in the suburbs of Chicago. In a recent interview for the New York Times, Cisneros relates some of the problems she experienced while writing the novel as her MFA thesis at the University of Iowa. She was criticized by her advisor for the excessive use of the word 'little,' an English alternative to the diminutive -ito in her Spanishspeaking Mexican household. She did not realize until she left Iowa: "I was writing a letter in Spanish and I thought, this is the voice of The House on Mango Street" (Gleibermann 2017). The linguistic conflict between Spanish and English, theorized by Gloria Anzaldúa in Borderlands (1987) as a relationship of dominance and resistance, also appeared in Junot 
Díaz' fiction. During his workshops at Cornell University, Díaz, a 2008 Pulitzer Prize winner, was reprimanded for the occasional use of Spanish slang in his (English-language) work. Both Cisneros and Díaz eventually found their place in the US literary field. ${ }^{12}$ Nevertheless, their anecdotes are exemplary of the clash between the Hispanic and the English literary tradition in the workshop milieu, that would eventually lead to the first bilingual MFA in Creative Writing in 2006 in El Paso, Texas, a city just on the border of Mexico and with a long history of bilingualism and multiculturalism. By the end of the decade, New York University opened its MFA with the support of the Spanish bank Santander, which sponsored the fellowship of Federico Flaco, the first writer with an MFA in the Granta list. In 2012, the University of Iowa opened its own Spanish MFA, and, in 2016, the University of Houston offered a PhD in Spanish Creative writing, headed by the Mexican writer Cristina Rivera Garza.

These programs not only filled in a gap in the US field for young Hispanic immigrants, they also attracted young writers from Latin America and Spain, who were drawn by the prestige and scholarships offered by these schools. Situated between the Spanish department of these universities and Creative Writing programs, presented as multiethnic, these new MFAs, despite their intended plurality, perpetuated the tradition of creative writing scholarship built up in the United States for over a century. The first program, in El Paso, is perhaps the most explicit in this appropriation and integration. According to the program's website and its course descriptions for the fall 2019 semester, classes of Spanish and Latin-American literature are complemented with technical courses of creating writing, using handbooks like Hamilton Sharon's Essential Literary Terms and Chris Albani's The Face: Cartography of the Void. El Paso's MFA also offers a class about creative writing pedagogy, since according to their website "(a)t some point all writers get to teach, either in high schools, community colleges, or independent literary workshops.” In the NYU and Iowa MFAs, even if their approach is less theoretical and more practical, Spanish workshops are complemented with the more classic courses in English where the workshop poetics are already in place.

In 2008, similar programs began to appear in the Latin America and Spain as well, when, for example, the MFA of Creative Writing at the National University of Colombia opened, more closely aligned with the university's cinema and art departments, than with that of literature. At the same time, the University Pompeu Fabra in Barcelona launched what has become the most prestigious MFA outside of the 
United States, with a program constructed between master classes given by Hispanic writers, and more technical courses, for instance the one taught by Jorge Carrion, based on James Wood's How Fiction Works. ${ }^{13}$ After the success of these initial programs, the MFAs spread throughout the Hispanic world: University of Sevilla (2009), National University Tres de Febrero, Argentina (2013), University Diego Portales, Chile (2015), among others. While a complete list of MFA creative writing programs in Spanish does not yet exist, according to the RED Programa de escritura de las Américas (Writing Program of the Americas), led by the University of Texas in El Paso, and the European Association of Creative Writing Programs, at least 13 programs are active today, spread between the USA, Latin America, and Spain, a number which is likely a significant underestimation.

All of these programs have writers from the post-Boom generation as instructors, mostly coming from the McOndo generation and the authors included on the first 'Bogota 39' list. While these writers became professionals without having MFAs themselves, they were nonetheless close to the workshop environment popularized by such programs, later finding teaching positions in them. In that regard, MFAs fulfill the function of institutional support, as outlined by McGurl, allowing writers earn a living which would have been difficult to obtain through literary work alone (2008). More recently, younger writers who were educated in international programs also found positions in their programs as teachers (i.e., Mónica Ojeda in Pompeu Fabra's MFA), or have even returned to their own countries to create new programs. The MFA of the Instituto Caro y Cuervo (2017) in Bogotá, for instance, was founded by young writers Juan Álvarez, Gloria Susana Esquivel, Giuseppe Caputo (who all three received their degrees from El Paso and NYU), and Juan Cárdenas (who, with Caputo appeared on the 2017 'Bogotá 39' list).

\section{THE IMPACT OF WORKSHOP Poetics on Hispanic Literature}

In spite of the resulting institutionalization of creative writing in the Hispanic field, a concomitant rise of Hispanic writing manuals was not established to support its own pedagogy. A search through the most prominent bookshops of Spain, México, and Argentina ${ }^{14}$ shows a lack of a Hispanic technical corpus beyond the poetics and essays of the Boom authors, or the more popular-orientated literary advice handbooks 
which merely translate or adapt the English formulas (e.g., Nerio Tello's Escritura creativa: Guía de indagación y práctica literaria [Creative Writing: Guide of Literary Inquiry and Praxis]). As a result, and in spite of their inherent cultural resistance, Hispanic MFAs remain, so to speak, at the mercy of Anglophone literary advice handbooks. This inevitably impacts the manner in which the new Hispanic literature is being and will be written, as well as how this literature will be read. ${ }^{15}$ In what follows, we will focus on one of the most famous and worn-out workshop adages: 'show don't tell.' Whereas the other two commandments singled out by Dawson 'read like a writer' and 'find your own voice' (Dawson 2005, pp. 87-120) can easily be adapted to different literary traditions, 'show don't tell' is strongly tied to a specific poetics, i.e., the English and French realist traditions of the late-nineteenth and early-twentieth centuries, particularly that of Flaubert.

Analyzing the literary advice from the 1930s, Dawson points out that the 'show don't tell' rule is intended to avoid lazy or long-winded writing (ibid., pp. 98-106). Taking the advice to extremes, however, entails the suppression of adjectives and leads to the predominance of verbs, that is to say, of actions. By the 1980s, the 'show don't tell' rule was associated with the predominance of literary genres such as dirty realism (led by authors like Raymond Carver or Dennis Johnson) in North-American MFAs, which was eventually canonized in Tobias Wolff's compilation The Vintage Book of Contemporary American Short Stories (1994) (Hardbach 2014, p. 20). Although a more Flaubertian and extensive examples, less in the vein of minimalism or dirty realism (for instance Jonathan Franzen, Lorrie Moore or Alice Munro) also exists, the popularity of 'show don't tell' still tends to privilege 'mimesis' (images) above 'diegesis' (an eloquent narrator) and results in a more distanced, observer point of view, as a primary feature of high-valued literature. As James Wood, critic of The New Yorker and author of How Fiction Works (so a prescriber of the US literary establishment), reminds us:

We hardly remark of good prose that it favors the telling and brilliant detail; that it privileges a high degree of visual noticing; that it maintains an unsentimental composure and knows how to withdraw, like a good valet, from superfluous commentary; that it judges good and bad neutrally; that it seeks out the truth, even at the cost of repelling us; and that the author's fingerprints on all this are, paradoxically, traceable but not visible. (Wood 2008, p. 39) 
Offering a sequence of images, the realistic style entails that commentaries between descriptions as well as the meddling of the Balzacian voice elaborating his opinions from one character to the next are eliminated, and instead favors the mute eye which is the narrator of Flaubert's L'Education sentimental. It relies on the capacity of images to enunciate, on the ellipsis as a primary technique, and on the supremacy of Hemingway's iceberg theory: "The dignity of the movement of iceberg is due to only one-eighth of it being above water" (Hemingway 1999, p. 260). The result is what Jacques Rancière calls in Le Destin des images (2003, The Future of the Image) 'phrase-images,' a set of images which, paired together, transmit an idea (the French philosopher gives the example of Zola's description of the preparation of the boudin noir (blood sausage) in Le Ventre de Paris as a counterpoint to the misery of the Second French Empire). This technique would later be borrowed and adopted for the cinema and is now commonly applied in film editing (Rancière 2003, pp. 58-60).

Even if this type of literature believes in an intelligent reader who is supposed to be an active agent in the construction of meaning, it has a propensity to become flat and repetitive. It denies the modernist efforts of writers from the beginning of the twentieth century who, focusing on the limits of language and structure, were actually fighting against the conventions of nineteen-century realism. Furthermore, this image-laden realism goes against the traditions of the Hispanic field and the more experimental styles of the Boom literature which, as Cortázar famously desired, look for a more active role of the audience in the construction of meaning. As a result, the literature born from the influence of the dirty realism seems like a factory of images, or a contest of who can communicate, through mere descriptions, the largest amount of ideas in the cleverest way.

In addition, as has been noted by McGurl, the similar background of literary MFA holders, due to an expansion of the middle-class and increased access to higher education in the post-war era (even in underdeveloped Latin-America), has produced a generation of lower-middle-class writers, obsessed with telling their own stories or, as McGurl puts it, with a self-reflexive fiction (McGurl 2009, p. 268). As a result, the literature became repetitive both in form (workshop poetics) and in content (self-reflexive). This also applies to many of the Hispanic writers who emigrated to the US, obtained MFA degrees, and appropriated the workshop poetics. In these cases, Carver's lower-middle-class hero is replaced 
by a working-class or lower-middle-class immigrant who has integrated into US society through (in the most self-reflexive/auto-fictional examples) access to higher education, such as the MFA, as in the works of Junot Díaz and Sandra Cisneros, as well as those of Daniel Alarcón Lost City Radio (2007) and Julianne Pachico The Lucky Ones (2018).

\section{CONCLUSION}

What, then, is the state of the contemporary fiction in the Hispanic world? Have the MFAs actually changed the way Hispanic writers approach literature? As mentioned above, the distancing from the Boom's avant-garde initiatives started well before the introduction of MFAs in the Hispanic literary landscape. In the 1990s, the McOndo and Crack generations looked to the US canon, for inspiration and in the hope of international recognition. This resulted in a workshop style of literature, even before the emergence and institutionalization of MFAs in the Hispanic field. The Alfaguara prizes, which can be considered a barometer of the mainstream literary tendencies in the Hispanic world, went to novels with these characteristics between 1998 and 2011, for instance, Xavier Velasco's Diablo guardián (2003, Guardian Devil), which follows the precepts of the McOndo manifesto, Santiago Roncagliolo's Rojo abril (2006, Red April), which pays homage to the simplicity of pulp fiction, and Juan Gabriel Vázquez El ruido de las cosas al caer (2011, The Sound of Things Falling), a relatively complex novel, while still applying realistic and traditional styles.

The workshop poetics appears even more clearly in the first novels of young Hispanic writers after 2010, most of which are the results of MFA theses, such as Susana Esquivel's Animales del fin mundo (2017, Animals at the End of the World). This novel, in an accomplished 'show don't tell' style, tangentially discusses Colombian violence in the 1980s from the point of view of a young girl who witnesses the divorce of her parents. A product of workshop poetics, the novel only differs in style from other competing US MFA works as Emma Cline's The Girls (2016) or Kristen Roupenian's Cat Person (2017).

Nevertheless, since we were dealing with descendants of Lope and not just of Poe, we also discover some resistance to these trends. Certain writers with an MFA appearing in the 2017 'Bogotá 39' list adopt a more transgressive approach, which can be seen to return somewhat to the more experimental approaches of Boom-generation novels. Giuseppe 
Caputo's Un mundo buérfano (2016, An Orphan World), for instance, is a Caribbean-Colombian nod to Reinaldo Arenas's or Manuel Puig's queer literature. Monica Ojeda's Nefando (2016) and Mandibula (2018, Jawbone), although responding to the workshop poetics, manifest new approaches to horror through surrealism.

Beyond the lists and the MFAs, we also see a strong movement toward a complex literature that pays homage to previous generations while seeking innovation. Fernanda Melchor, for instance, who does not hold an MFA degree, but who attended Mexican literary workshops, was inspired by the complex language, structure, and perspective of García Márquez' El otoño del patriaca (1975, The Autumn of the Patriarch), to write her Temprada de huracanes (2017, Hurricane Season), one of the most acclaimed Hispanic novels of the last decade. Likewise, the Colombian author Carolina Sanín, who holds a PhD in Hispanic literature and who has also imparted workshops in Colombian universities, published Somos luces abismales (2018, We Are Abyssal Lights), a book that mixes poetry, fiction and testimony and thus escapes the cage of the 'show don't tell' rule. Similarly, Samanta Schweblin's Distancia de rescante (2014, Fever Dream) seeks to emulate, in the first person, the voice of a poisoned and delirious woman, breaking with realism in the process.

While for a long time Hispanic literature remained attached to the Romantic view of the writer-as-genius, the field changed in the latetwentieth century toward a more work-driven poetics. This change, due to both US literary and MFA influence, implied not only the acceptance of writing as a learnable trade, but also a compliance with the poetics developed in Anglophone workshops in the twentieth century. Nonetheless, even if Hispanic literature has shown an inclination toward these types of poetics and seemed to submit to the domination of Anglophone literature in a global market, the change has not been complete. The phenomenon has also inspired a form of resistance and cooperative exchanges, leading to a re-invigoration of Hispanic literature.

The popularity of MFAs of creative writing in Spanish, and the increasing number of graduates, will certainly continue to expand the industry of creative writing in the Hispanic field, and will likely continue to propagate the North American workshop style on both sides of the Atlantic. But, while the majority of graduates may perpetuate the nowtrite imperatives of workshop poetics, a freer approach is possible, as the Hispanic programs continue to develop their own identities and MFA syllabi. Fostering new spaces for literary experimentation, they may in 
turn influence the Anglophone field of production as well. As Lope, or the Boom authors did before, the current generation of new Hispanic writers may well take the advice of 'show don't tell,' and decide to lock it in with six keys, while proceeding to write in their own ways.

\section{Notes}

1. This chapter will refer to the literature produced in all the Spanishspeaking regions, that is to say, largely Spain and Latin America. Even if it is possible to distinguish between different national traditions, or at least to draw a line between Latin America and Spain, due to historical reasons (i.e., colonialism and the existence of interconnected literary centers, mostly organized around Spain, Mexico, and Argentina), the Hispanic literary field can be considered as a whole.

2. The underrepresentation of women in the present article is due to the still strong patriarchal domination of the Hispanic literary world. The reception of the Boom generation, for instance, considered female authors as second-class members of the movement. Recent scholarship has brought back some of them into consideration, for example, the Mexican writer Elena Garro (1916-1998) who was for a long time mainly regarded as the wife of Octavio Paz now receives a more important place in the canon.

3. In various essays, Darío condemns the literature of the Spanish Peninsula as archaic, as though having remained in the seventeenth-century Golden Age, instead favoring the influence of American and French literature, and calling for a brotherhood of writers, even defending the concept of writing as work.

4. Fuguet's choice of the name McOndo is a wordplay between Macondo, the fictional town of García Márquez's One Hundred Years of Solitude and the prefix Mc- associated with McDonald's and the culture of late capitalism to which he wanted to belong.

5. Both 'Bogotá 39' lists only incorporate Latino authors and have a strong bias toward Colombian writers and culturally aligned countries such as Mexico and Peru. Granta's list is shorter, with only 22 writers, giving privilege to the Spanish and Argentinean authors. None of the lists is inclusive in terms of gender and ethnic diversity.

6. In terms of international impact, Roberto Bolaño (1953-2003) was the best-known Hispanic writer after Gabriel García Márquez in the US and Europe. A combination of sociological and literary circumstances, as well as its literary quality, made his posthumous novel 2666 (2004) a US best seller in 2008 (see Corral and Andrews). 
7. Besides Díaz, there are two other authors with MFAs in Script Writing, a more accepted line of study in the Hispanic field, given the novelty of the medium.

8. In some countries such as Mexico, the role of the State as grant provider is relevant. Nonetheless, it is not systematic throughout the Hispanic literary field.

9. Pierre-Michel Menger in Le travail créateur refers to the Pareto Law to describe income in artistic fields, that is $20 \%$ of artists have $80 \%$ of the total global revenue (Menger 2009, pp. 268-343).

10. For instance, the Cuban Revolution (1959), the Dominican Civil War (1965), the Argentina's National Re-organization Process (1976-1983), the Pinochet dictatorship in Chile (1973-1990), among others.

11. Cf. "ACS Demographic and Housing Estimates / 2013-2017 American Community Survey 5-Year Estimates", 2017; "Race and Hispanic or Latino Origin: 2010 / 2010 Census Summary File 1", 2010; "Race and Hispanic or Latino: 2000 / Census 2000 Summary File 1 (SF 1) 100-Percent Data", 2000.

12. This field was constructed in the twentieth century, primarily on the storytelling of the immigrant experience (Mukherjee 2011).

13. James Wood is one of the New Yorker's literary critics who hassled the workshop "esthetics and the world literature" in recent years.

14. I consulted on the online catalogs of: La Central and La Casa del Libro (Spain); Fondo de Cultura Económica and Gandhi (Mexico), and El Ateneo (Argentina).

15. As Levy points out, the workshop industry not only produces writers, but also creates skilled readers who will become the next buyers of short stories and novels (Levy 1993).

\section{REFERENCES}

ACS Demographic and Housing Estimates/2013-2017 American Community Survey 5-Year Estimates. 2017. Washington.

Andrews, Chris. 2014. Roberto Bolaño's Fiction: An Expanding Universe. New York: Columbia University Press.

Anzaldúa, Gloria. 1987. Borderlands La Frontera: The New Mestiza. San Francisco: Aunt Lute Books.

Alas, Leopoldo. 1896. Crítica Popular. Valencia: Biblioteca Virtual Miguel de Cervantes. http://www.cervantesvirtual.com/obra-visor-din/critica-popula r-0/html/ff68712a-82bl-1ldf-acc7-002185ce6064_3.html\#I_0. Accessed 18 November 2019.

Ayén, Xavi. 2014. Aquellos años del boom. Barcelona: RBA. 
Bioy Casares, Adolfo. 1988. A la hora de escribir, ed. Esther Cross and Félix della Paolera. Barcelona: Tusquets.

Carbajal, Brent J. 2005. The Packaging of Contemporary Latin American Literature: La Generación Del Crack and McOndo. Confluencia 20 (2): $122-132$.

Cascales, Francisco. 1617. Tablas poéticas. Alicante: Biblioteca Virtual Miguel de Cervantes. http://www.cervantesvirtual.com/obra-visor/tablas-poeticas-2/ html/fee79db6-82bl-1ldf-acc7-002185ce6064_2.html\#I_0_. Accessed 18 November 2019.

Castro Caycedo, Germán. 1976. Interview with Gabriel García Márquez. RTI. https://www.youtube.com/watch?v=8bu8XC7QW4s. Accessed 18 November 2019.

Cervantes, Miguel de. [1604] 2003. El Quijote de La Mancha 1. Madrid: Cátedra.

Corral, Wilfrido H. 2011. Bolaño en inglés: la nueva literatura mundial y el apóstata. In Roberto Bolaño: la experiencia del abismo, ed. Fernando Moreno: 365-404. Santiago de Chile: Lastarria.

Darío, Rubén. 1915a. La vida de Rubén Darío. Barcelona: Casa Editorial Maucci (Biblioteca Virtual Miguel de Cervantes). http://www.cervantesvirtual.com/ obra/la-vida-de-ruben-dario-0/. Accessed 18 November 2019.

- 1915b. Prosas profanas y otros poemas. Paris: Librería de la viuda de C. Bouret (Biblioteca Virtual Miguel de Cervantes). http://www.cervantes virtual.com/obra/prosas-profanas-y-otros-poemas/. Accessed 18 November 2019.

- 2003. El modernismo y otros textos criticos. Alicante: Biblioteca Virtual Miguel de Cervantes. http://www.cervantesvirtual.com/obra/el-mod ernismo-y-otros-textos-crticos-0/. Accessed 18 November 2019.

Dawson, Paul. 2005. Creative Writing and the New Humanities. New York: Routledge.

Forster, E.M. [1927] 1985. Aspects of the Novel. New York: A Harvest book.

Fraile Amador, María del Pilar. 2018. Textos Sobre Escritura Creativa: El Origen de Una Disciplina. Tropelias: Revista de teoría literaria y literatura comparada 29: $381-402$.

Fuentes, Carlos. 1999. Cátedra Alfonso Reyes: Carlos Fuentes. Monterrey Institute of Technology and Higher Education. https://www.youtube.com/ watch? $=$ =Gtp5S4ly2xw\&t=393s. Accessed 18 November 2019.

Fuguet, Alberto, and Sergio Gómez. 1996. McOndo. Santiago: Grijalbo Mondadori.

Gleibermann, Erik. 2017. Seeking a Voice, via a Bilingual M.F.A., in Writing and in Life. The New York Times, November 27. https://www.nytimes. com/2017/11/02/education/edlife/bilingual-mfa-writing.html. Accessed 18 November 2019. 
Góngora, Luis de. 2006. A Cierto Señor Que Le Envió La Dragontea de Lope de Vega. In Sonetos a Lope de Vega. Siglos XVI a XX, ed. Ramón García González. Alicante: Biblioteca Virtual Miguel de Cervantes. http://www.cer vantesvirtual.com/obra/sonetos-a-lope-de-vega-siglos-xvi-a-xx-0/. Accessed 18 November 2019.

Harbach, Chad. 2014. MFA vs NYC: The Two Cultures of American Fiction. New York: $\mathrm{n}+1$.

Hemingway, Ernest. [1932] 1999. Death in the Afternoon. New York: Scribner Classics.

Hilliard, Christopher. 2006. To Exercise Our Talents: The Democratization of Writing in Britain. Cambridge: Harvard University Press.

Levy, Andrew. 1993. The Culture and the Commerce of the American Short Story. New York: Cambridge University Press.

Lope de Vega, Félix. [1609] 1914. The New Art of Writing Plays, ed. Brander Matthews. New York: Dramatic Museum of Columbia University.

- [1609] 2006. Arte nuevo de hacer comedias. Madrid: Cátedra.

Luzán, Ignacio de. 1737. La poética o reglas de la poesía en general y de sus principales especies. Zaragoza: Francisco Revilla (Biblioteca virtual Miguel de Cervantes). http://www.cervantesvirtual.com/obra/la-poetica-o-reglas-de-lapoesia-en-general-y-de-sus-principales-especies- $0 /$.

Maier, Linda S. 2011. A McOndo Writer's Take on Literature in the Era of Audiovisual and Digital Communication: The Case of Alberto Fuguet's Las Películas de Mi Vida. Hispania 94 (3): 406-415.

McGurl, Mark. 2009. The Program Era: Postwar Fiction and the Rise of Creative Writing. Cambridge: Harvard University Press.

Menger, Pierre-Michel. 2009. Le Travail Créateur. Paris: Seuil.

Miles, Valerie, and Aurelio Major. 2010. Foreword. Granta Magazine 113. https://granta.com/foreword/. Accessed 18 November 2019.

Miles, Valerie, Aurelio Major, et. al. 2010. Granta 113: The Best of Young British Spanish-Language Novelists. London: Granta Publication. https://granta.com/issues/granta-113-the-best-of-young-spanish-lan guage-novelists/. Accessed 18 November 2019.

Mukherjee, Bharati. 2011. Immigrant Writing: Changing the Contours of a National Literature. American Literary History 23 (3): 680-696.

Pérez, Alberto Castillo. 2006. El Crack y Su Manifiesto. Revista de La Universidad de México 31 (September).

Pope, Randolph D. 1996. The Spanish American Novel from 1950 to 1975. In The Cambridge History of Latin American Literature, vol. 2, 226-78. Cambridge: Cambridge University Press.

2000. Race and Hispanic or Latino: 2000 / Census 2000 Summary File 1 (SF 1) 100-Percent Data. Washington. 
2010. Race and Hispanic or Latino Origin: 2010 / 2010 Census Summary File 1. Washington.

Rancière, Jacques. 2003. Le Destin Des Images. Paris: La Fabrique.

Valera, Juan. 1934. Apuntes sobre el nuevo arte de escribir novelas. Madrid: Imprenta Alemana.

Vargas Llosa, Mario. 2003. Letters to a Young Novelist, trans. Natasha Wimmer. New York: Picador.

- 2011. Cartas a Un Joven Novelista. Madrid: Alfaguara.

Wandor, Michelene. 2004. Creative Writing and Pedagogy 1: Self Expression? Whose Self and What Expression? New Writing l (2): 112-123.

Wood, James. 2008. How Fiction Works. New York: Farrar, Straus and Giroux.

Open Access This chapter is licensed under the terms of the Creative Commons Attribution 4.0 International License (http://creativecommons.org/licenses/ by $/ 4.0 /$ ), which permits use, sharing, adaptation, distribution and reproduction in any medium or format, as long as you give appropriate credit to the original author(s) and the source, provide a link to the Creative Commons license and indicate if changes were made.

The images or other third party material in this chapter are included in the chapter's Creative Commons license, unless indicated otherwise in a credit line to the material. If material is not included in the chapter's Creative Commons license and your intended use is not permitted by statutory regulation or exceeds the permitted use, you will need to obtain permission directly from the copyright holder.

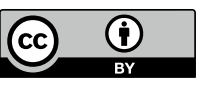

